\title{
OverComing DominATION THROUgh SelF-Representation: Gay Men's EXPERIENCE IN 1960s San Francisco
}

\author{
J. Todd Ormsbee, Ph.D. \\ University of San Francisco
}

During the 1960s, many gay men experienced American culture as domination, as an intrusive and oppressive force outside their immediate control. The material side of this domination took the obvious, in-your-face forms of police raids and entrapment, exclusion from meaningful social interactions such as family and church, and at its worst, incarceration and institutionalization. But there was also an internal, affective experience of domination, which arose from the continual stream of information about homosexuality circulating in the American culture at the time. Prior to World War II, the official medical, scientific, political, religious, and legal discourses concerning sexual behaviors and desires had worked to make homosexuality intelligible to a heterosexual dominant and to thereby render it containable and non-threatening to the heterosexual order. The production of this kind of knowledge about sexuality continued after World War II, growing more intense and restrictive as the culture of the United States tightened and grew more restrictive at the onset of the Cold War. ${ }^{1}$ This flow of information served to produce dominant meanings ascribed to homosexuality, meanings produced from the outside by non-homosexuals with particular effective ends, namely the containment of a "social disease." Starting in the late 1940s, some gay men had begun to leave traces of their first-hand experiences of their own sex and desire and, more importantly, of their struggles against these dominating official discourses. By the early 1960s, gay men in San Francisco were actively engaged in a cultural battle for the ability to define the 
meaning of their own sexual desires, behaviors, relationships, and communities, a battle they fought in part in the pages of the city's nascent gay press. ${ }^{2}$ These gay men left a record not only of actual encounters with agents of the official public sphere, but more importantly they reported their feelings, their experience of those encounters with the police, the city, state, and federal governments, church and synagogue, family and friends, employers, and psychiatrists. Their accounts of what it was like to be "gay" during the period reveal no easy — and certainly no causal — relationship between the disciplining medical, sexological, and legal discourses of sexual pathology and their gay lives. Rather, gay men were seeking self-consciously to understand their sexual desires and behaviors, generating new knowledge about their gayness for themselves, making it intelligible to a gay audience in ways commensurate with their own experience of their desires and behaviors. This new knowledge ran counter to the official discourses of the heterosexual order, so gay men had to work hard to create a cognitive space that would nurture their own meanings of homosexuality and that would support their emerging gay communities.

The city of San Francisco provided a particular context within which the city's gay men could wage these battles, a city with a core culture of sexual toleration overlaid with Cold War sexual repression. ${ }^{3}$ In 1961, Jose Sarria, a drag performer, ran for the Board of Supervisors of San Francisco concurrent with the formation of a new gay rights organization, the League of Civil Education. The LCE marked a shift in gay activist strategies away from 1950s tactics of having straight "experts" represent the homosexual cause to the general public, toward direct assertion of gayness in the public sphere by gay people themselves. By 1972, the gay community of San Francisco sponsored its first gay pride parade and festival, marking another significant shift in thinking about being gay in the public sphere. Between 1961 and 1972, as part of their entrance into the public sphere as gay men and with the increasing visibility of gay men in local and national media, San Francisco's gay men began to confront their domination in new ways. Both the increasing public presence of gay activists and the new ways they produced to think about homosexuality created a 
social environment that would foster a counter-production of knowledge about homosexuality.

During the 1960s, the medical discourses, which had established the pathology of homosexuality well before 1961, combined with the religious discourses, which had long since affirmed the immorality of homosexuality, to justify and enable the coercive state and interpersonal interventions into gay men's lives. The direct violence of both official and unofficial agents of the public sphere added a physical dimension to the domination of the heterosexual order and effected its internalization within gay men, who self-surveilled in order to avoid the consequences of their sexual difference. Thus, gay men experienced the dominant meanings of homosexuality in their bodies, rendering the experience personal, internal, emotional, and cognitive. They felt their domination as a series of outside forces continually battling in their psyches and on their bodies for control of their lives. ${ }^{4}$ The dominant meanings of homosexuality had the power to discipline not only gay men's behaviors, but also their feelings and self-perceptions. But their lived experiences ultimately gave them the power to resist and refuse those discourses and to create something else. The negative value placed on homosexuality by the heterosexual order imposed a kind of psychic weight on gay men, who carried that weight everywhere and had to be constantly vigilant against its deleterious effects. As gay men began to see themselves and their sexuality as a moral Good, they had to do so against the weight of dominant cultural meanings. Thus, gay men and women fought a battle not only for political recognition, but for the power to create their own meanings for their own sexuality as they experienced it. But this project required a constant vigilance against a symbolic order that sought to wipe them out. In other words, overcoming the kind of symbolic violence perpetrated by medical, religious, legal, and pop cultural discourses took a lot of work.

\section{The Experience of Domination}

Inasmuch as their sexual desires and behaviors occurred in a complex environment that included public institutions, which tried 
actively to suppress their sexual expression, gay men often tried to make sense of their sexuality in terms of the medical and legal discourses that dominated them. Such discourses provided authoritative explanations for the causes of homosexuality and the meaning of homosexual behavior in view of its "causes." With the aegis of Science and Religion behind such authoritative discourses, their intended effect was to control the behavior and even the desires of same-sex attracted men. But gay men's interaction with these pathologizing discourses reveals a disjuncture between the intended disciplining effect and gay men's actual experience of their sexual desires and social lives. That is to say, the way gay men used the official knowledge of homosexuality, the ways they rejected some parts and claimed other parts for their own ends, ran counter to the intended effects of the heterosexual order. Indeed, gay men's increasing frustration arose out of this disjuncture between what authorities argued should be homosexual experience and what they actually experienced. They did not feel sick, lonely, incapable of love, attracted to children, immature, underdeveloped, or womanhating. Rather, they found that in their gay communities, they thrived, that their same-sexuality was as integral to their well-being as any form of sexual desire and relationships.

In their publications, San Francisco's gay men had already begun to confront directly and publicly the heterosexual symbolic order, which represented gay men as effeminate, ${ }^{5}$ irresponsible and free-wheeling, ${ }^{6}$ sex-crazed, ${ }^{7}$ alcoholic, ${ }^{8}$ members of a nationwide crime syndicate or secret society with plans to subvert America, ${ }^{9}$ the cause of the decline of Western Civilization, ${ }^{10}$ a contagion spreading throughout the nation, ${ }^{11}$ and the "Typhoid Mary" of America spreading venereal diseases. ${ }^{12}$ The combination of psychiatry, religion, and mass media had created an environment in which powerful negative images of the homosexual male circulated. This cluster of images served to justify, in the minds of the American public, the control of gay men and gay groups and the repression of their behaviors and desires. In other words, the dominant images of homosexuality enabled the domination of homosexuals by sanctioning the repressive acts of state agents and individuals whose perception was refracted through anti-homosexual 
habits of mind, such that every-day Americans enacted domination through their social and cultural practices. The systems of meaning surrounding homosexuality produced individuals (both gay and straight) who in turn reproduced those dominating meanings through their social interaction and cultural practices. As many have noted, these images served to reinforce heterosexuality in the negative by producing a sexual Other.

In 1970, one writer explained the problems that such negative representations had on gay men.

In our society, the simple fact that I love other men means (for the most part) that I must swish, that I must slur my words, that I must be an alcoholic, that I must be a 'mamma's boy,' that I must be subservient (a waiter, artist, or busboy), that I must hate women, and that I must sexually desire anything with a cock! ... Gay liberation means rejecting the stereotype. The only fact that I can accept (and take pride in) is the fact that I love other members of my own sex. I accept my sexual preference as a part of myself, yet it is only one small aspect of myself. I am a human being - varied complete and beautiful. IA 1.2, 2.

So many gay men experienced these images as meanings of homosexuality imposed from the outside by non-homosexuals, which had little if any correlation to their actual experience of being homosexual. From the beginning of the period in 1961, the gay men participating in the emerging gay and lesbian activist organizations and in the city's gay press fought to reject such dominating images outright by replacing them with their own counter-images of gayness. They hoped to imbue these counter-images with some kind of meaning that would sustain an emotionally healthful and happy life. But the effects of the dominating images ran deep and often seemed intractable. Interestingly, while most writers expressed the sense that they were being oppressed in some way more insidious than structural discrimination and police repression, they disagreed about what the source of their oppression was and on how that oppression actually affected them.

Out of their experiences with these dominating images and representations, gay men countered the dominant heterosexual 
culture and produced new knowledge of their own sexuality; their experience provoked them to produce meanings that "made sense" to them given their experience. Experience, here, can be a troubling concept, inasmuch as it is often used uncritically as evidence of historical realities, as if experience weren't shaped by the society and history that produced it. The concept has been much criticized as an attempt to lend authenticity and authority to the individual, thereby making subjectivity into something it cannot be. ${ }^{13}$ John Dewey's notion of experience comes from his organic theory of knowledge and situates experience as part of the process of cognition, the production of knowledge, as already-knowing individuals interact in an eminently complex social, cultural, and obdurate universe rife with meanings. In this sense, experience is not an observation in the scientific sense, nor is it knowing itself (although knowledge arises from experience). Rather experience is a process of undergoing, "a process of standing something; of suffering and passion, of affection, in the literal sense of these words. The organism has to endure, to undergo, the consequences of its own actions. Experience is no slipping along in a path fixed by inner consciousness." 14 Primary experience, for Dewey, must be separated analytically from the thoughts experience produces, from the evaluation and appraisal of experience, which is the human effect of experience. ${ }^{15}$ Yet experience is constitutive of thought as it provokes individuals to think about what they experience. Individuals then work to render their experience intelligible by creating systems of meanings to explain their experience and give it social meaning that can be shared and communicated. Dewey's concept explains the connection between experience and culture, where culture and its objects are experienced and must therefore not be wrenched from the process of experiencing as if they existed separately; culture is constitutive of experience and experience is constitutive of culture. ${ }^{16}$ When conceived of in this way, gay men's experience of domination led directly to the production of new cultural meaning systems - meanings counter to those produced by the dominant culture-for their sexual desires, sexual acts, and social relationships.

The kind of domination produced by dominant cultural mean- 
ings of homosexuality was more personal, more inward, and in some ways more profound than the structural oppression of state apparatuses. This was a domination that evoked feelings about the self, particular kinds of self-perceptions and an affective orientation towards the self that had dire consequences for the health and happiness of the individual. Sometimes the oppression often came as an effective silence, which served to keep gay men separate from each other. At other times, it took the form of the general disapproval of the majority of Americans. ${ }^{17}$ "The established institutions perpetrate the silence about love between men in order to keep the homosexual isolated from his sexual peers," wrote one gay man ( $V R$ March 1966, 11). Most often, oppression came from "experts" who expounded to the public the "truth" about homosexuality. Gay men struggled to overcome this particular kind of cultural, symbolic domination ${ }^{18}$ in their self-perceptions by creating new, positive ones, which in turn came to define gay men's culture in San Francisco between 1961 and 1972. ${ }^{19}$

By the mid-1960s, some gay men were starting to think critically about the personal effects of socially constituted regulations of their sexuality, moving beyond the common 1950s conception of oppression as merely a structural or legal issue. They were now seeing themselves in relationship to the heterosexual order. "[The homosexual] is brainwashed into following rules which are privately flouted by almost every [heterosexual] citizen every day. ... Empty, frustrated, and lonely heterosexuals are forced to compare themselves with what seems to be defiance of law and freedom incarnate: the gay boy-ever promiscuous, ever laughing, ever drinking, and whoring the night away" ( $V R$ Jan. 1965, 5). But what the straight coveter missed was the domination perpetrated by the very rules the homosexual seems to flaunt. "The only difference is that when he [the homosexual] faces up to his moral convictions and acts on them, he invites police harassment and often jail. The homosexual is required to be homosexual in a hypocritically heterosexual culture." So gay men had come to feel their domination not as simply the police harassment, but more a cognitive experience of knowing that the simplest form of homosexual self-expression was forbidden, strictly patrolled and im- 
mediately punished, where expressing oneself was a source of danger. The daily task of the homosexual was "to grapple with the alienation the individual homosexual experiences between himself and his fellow man" (VR Aug. 1967, 14-15).

The term "alienation" appeared more and more often as a descriptor for the experience of being homosexual in America as the 1960s came to a close. As college students and graduate students moved into leadership roles in the emerging gay liberation organizations and as the overlap of revolutionary ideologies in various liberation movements progressed, certain aspects of Marxist critique took prominence in the gay psyche. Robert Cole wrote, "A homosexual, no matter how integrated into the heterosexual society, is alienated from that society by virtue of the fact [of his homosexuality]" (VR Aug. 1967, 14-15). Alienation meant a hyperawareness of one's socially unacceptable differences, of ones "faults" (VR Dec. 1967, 18). Some gay men began to rethink their common practices in terms of alienation, such as when one writer linked cruising for sex to a reaction against the "fear of abandonment and the need to be dependent on others" (VR June 1968, 12). Another man wrote of how the social conceptions of homosexuality put him in the mental state where he thought the only way to be accepted or to find peace was as a second-rate man. "The homosexual life was a desperate mirage and the most I could expect to find in the way of a personal growth or expansion was to be accepted in more oppressed parts of society as a poor man's 'woman,"' (GS Aug.-Sept. 1971, 11).

By the late 1960s, gay men's publications were actively seeking to replace negative, dominating representations with a positive affect vis-à-vis homosexuality, namely Gay Pride; and they did so by directly confronting and engaging the inaccurate and oppressive meanings that had been ascribed to them. "[S] ubjected to a barrage of straight propaganda ... we grew up thinking that we're all alone and different and perverted. ... The television, billboards and magazines pour forth an unreal idealization of male/ female relationships, and make us wish we were different, [that] we were "in," (SFFP Dec. 22-Jan. 7, 1970, 3-5). In this now famous "Gay Manifesto," Carl Whitman argued that there were four 
kinds of oppression: first, physical attacks, or "lynching"; second, psychological warfare as described above; third, self-oppression, such as "'Don't rock the boat,' 'things in SF are ok,' gay people just aren't together,' and 'I'm not oppressed' - these lines are right out of the mouths of the straight establishment"; and fourth, institutional oppression that makes gay relationships illegal.

But gay men did not agree on what their oppression felt like, or on its origins. Some gay men tried to make sense of being dominated in terms of their difference. "[The homosexual] is different. That's all that is wrong. He is the solitary white crow in the flock and all other crows peck him to death because he is not like them" (SFFP Oct. 1, 1969,12). Others argued that silence was the worse, when homosexuality was ignored or when homosexuals were treated as if they weren't different. "'I was Homosexual and you oppressed me in silence.' Silence surrounds us like an unfriendly night, it stands before us like a wall one can see and touch, but it is never really something you can come to grips with.... We are what the heterosexual wants to be blind to" ( $A A$ July 20, 1970). So the writers of Agape and Action rejected outright the heterosexual dominant: "Don't Adjust Your Mind; There's a Fault in Reality" (Aug. 25, 1970, 3). Likewise, The Effeminist's writers articulated the feelings of oppression and their purpose to control gay men and women. "Mystification, the creation of a sense of powerlessness, incapacity, smallness in the face of daily life in oppressed peoples is a standard technique of control in our modern world" (TE 1.2, 5-6). And Bill Miller wrote extensively of the cognitive and emotional cost of this oppression. "I am beginning to realize the tyranny which my conscious, thinking mind holds over the rest of my existence, and that the one thing which dominates my thoughts and dreams is the fact that I am gay" (GS Aug.Sept. 1970, 14). Miller felt that because of the cultural interdictions against homosexuality, his ability to express his feelings had been stunted.

Other gay men turned their critique on each other. Ralph Schaffer argued that many of the forms of gay culture were the direct result of accepting one's domination, something he dubbed "oppression sickness." 
Oppression sickness arises out of the oppression of gay people by our society which suppressed the natural expression of feeling - especially sexual feelings - in interpersonal relationships. ...gays not only internalize feelings of guilt, fear, shame, and inadequacy, they also have to devise substitutes for the rights of citizenship not available to them. GS April 1972, 15.

One of the primary effects of oppression was to cause gay men to value heterosexuality, which Schaffer connected to the value of "respectability" espoused by many gay men. These were the worst, for Schaffer, and he wasted no time in pronouncing harsh judgments upon the men he called "victims of oppression." "He does not really relate well to his peers sexually or intellectually and tends to tear down others like himself. His wounded ego is constantly trying to wound others." Schaffer does offer a positive approach to overcoming the inner effects of oppression. " 1 . Openly declare your gayness to the whole world and assert it with pride. 2. Take action against the real enemies. ... 3. Get concretely involved in gay community affairs. ... 4. Live openly and with honesty. Search for your own lifestyle." Schaffer represents a common current in gay male culture during the early 1970s, where some men who saw themselves as liberated turned their ire on other gay men.

Schaffer's positions provoked sharp responses, however, even among his fellow gay libbers. The following issue of Gay Sunshine carried critical responses to Schaffer's theory, underscoring the variety in gay men's experience of domination and their concomitant understanding of its effects on them. "[L]iberation, except by a purely subjective and personal interpretation of it, cannot be measured by [Schaffer's] criteria; it is instead the result of the degree of control a person has over the totality of his life" (GS May 1972, 7). For this letter writer, becoming psychologically liberated and being socially liberated was not the same thing. "[A] personal triumph over this conditioning in no way alleviates the objective social oppression individuals have been liberating themselves [from], in various limited ways, throughout human history." The writer argued that Schaffer's understanding of oppression and liberation removed domination from its social context, 
thereby cutting off the possibility of truly fighting for liberation. Three other men, Ned Tuck, Michael Cox, and Ralph Hill, also weighed in to counter Schaffer's theory of oppression sickness (see GS May 1972, 14). Cox in particular inveighed against Schaffer's mistake in only seeing the sickness without accounting for the "social pressures that provoke their responses." For Cox, this pointed to the necessity of the gay community to produce its own politics and values, "a world-view which does not see men and women as passive, vicious stereotypes, and which does not assess people in terms of their sexual performance." For Cox, this was the only way to stop reproducing the vicious lies of the dominant culture.

The notion of the "heterosexualized homosexual," that heterosexual values effected a symbolic domination of homosexuals, resonated among many gay men as they confronted the effects of being raised in what later queer theorists would call a heteronormative society. ${ }^{20}$ Heterosexual culture produced in gay men expectations, desires, and social statuses that were at odds with their experiences of themselves, their lives, their relationships, and their sexual desires. "Some of my expectations are thinking I should be heterosexual, thinking I should fall romantically in love with someone, and that any relationship short of this isn't worth my time that I should achieve success, that I should be productive" (GS Aug.-Sept. 1970, 14). And when expectations weren't met, "I feel inadequate. ... I feel the cause must be something wrong with me not with what I expect, because my expectations are created and reinforced by my cultural experience.... I feel inadequate because my head is forcing me to feel inadequate."

One gay man reported the pain of simply trying to understand what his same-sex desires were and what they meant. "The very fact that I must go though this awesome process is the essence of gay oppression" (GS Oct. 1970, 10). For him, this dynamic of heteronormativity pushed him to talk to his father about pictures of naked women to prove his normality, while never to consciously taking account of his desire for the other boys in his gym class. "It was the result of a system of oppression, of a society which will not accept and which actively condemns the love I feel for other 
men." Also foreshadowing contemporary queer theory, some gay men located their domination in a restrictive homo/hetero binary. "'Either/or' really sums it up. As a fundamental concept, it is basic to the source of gay oppression ... Without the dualistic concept 'heterosexual/homosexual,' we would not be set apart and condemned" (GS Oct.-Nov. 1971, 7). They found the binary, the two-fold choice, with moral weight added on, to be the source of their domination. They argued that the homo/hetero binary caused gay men to question their masculinity, because if they desired a man, then wouldn't that make them a woman? With "the insistence of heterosex" homosexuality became "a variant of pattern, an additionality, something bizarre and forbidden, and only in the context of degenerate heterosex ... a degeneracy per se within a degeneracy not per se" (TE May 1971, 1). Thus, homosexuality became the sign of degenerate heterosexuality, "Total degeneracy ... not degenerate monosexual relationships, on a par with the portrayal of heterosex in its degenerate forms, but the sign of degeneracy, one of the hallmarks of it."

Ultimately, these gay men experienced the heterosexual symbolic order as the locus of oppression and the source of oppressive cultural habits within the gay community. Speaking of older gay men, one writer argued, "We did not really create our fairyland: the hets did. ... It was reserved just for us as our very special place to live our very special way of life and it provided laughs for the hets.... Despised as we were, we were still their pampered pets in gilded cages" (GS Jan. 1972, 3). Morgan Pinney realized how the simple assumptions of heterosexuality could, when accepted by a gay man at the personal level, control his decisions to the detriment of his personal life. When he and his partner went to their respective families' homes for thanksgiving, Pinney realized that "our biological parental families won out over our self-created homosexual families. In doing so, we, once again disavowed the validity of gay life and helped to further, permanently establish our lives as second-best, transient, light, unimportant" (GS Jan. 1972, 11). Pinney felt that only a real gay community that truly believed that "Gay is Good," that is to say, a community that behaved in daily life as if Gay Were Good, could relieve the kind of 
intense personal oppression he had experienced and in turn support healthy gay relationships. "At every possible point, we must make those moves which re-affirm our homosexual relationshipsand we must do so in the face of innumerable aspects of our culture which tell us differently. Only we can liberate ourselves. One suggestion? Let's make certain that we spend Christmas with our gay families."

To the extent that homosexuals seemed to suffer from extremely low self-esteem or unbearable feelings of guilt, the cause came to be seen as not a natural defect in the homosexual, but as a flaw in society - alienation resulting from domination - that constantly fed the gay man "an unpleasant image of himself from the behavior of others towards him" (VR March 1969, 16-17). ${ }^{21}$ Thus, gay men had begun to refuse the explanations of the heterosexual order, which claimed that negative emotions and depressed psyches were inherent in homosexuality, and to turn the blame outward onto the heterosexual system. Oppression emerged out of the unfortunate meeting of "his own sexual predestination and society's outdated moral standards" (VR April 1969, 13-14, 25). ${ }^{22}$ Some gay men began to look with compassion upon each other, understanding the link between their suffering and the environment they lived in. One reviewer of the movie version of Boys in the Band, for example, argued that what made the performance he saw so powerful was that one of the actors "allowed his audience to see that beneath the "screaming fag' lurks a sensitive and deeply hurt human being" (VR Jan. 1970, 18) ${ }^{23}$ Of course, the most devastating effect of oppression was an inner pain so intense it led to utter hopelessness and suicide. Rev. Ray Broshears exclaimed, "Due to the oppression by the heterosexual society, most gay people are forced to take their own lives in great numbers each year" (GS Feb.-March 1972, 10).

As the gay press had begun to think critically about gay men's domination, they began to imagine a liberated life, or a life free from symbolic domination, and how that might be possible. It was here that gay men made the leap from substantive political action to the cultural work of overcoming symbolic domination by seeking to replace or adjust the perceptions and practices of gay men 
themselves. "[T]hese [low] levels of functioning are the result of social-psychological oppression and how they cripple the human potential of gay people. Where does the liberated individual fit into this scheme?" (GS Jan. 1972, 5). Self-acceptance had been touted from the times of Guy Strait's early newspaper in 1961 as the fastest way to healing the wounds of oppression. By the 1970s, the early notion of self-acceptance had morphed into consciousnessraising, another borrow from the Marxist movements of the period. "And the degree of misery or happiness in their lives depends on their level of consciousness. Self-acceptance in a hostile society is not easily won" (VR July 1970, 12). But others argued for a more simple solution: "[T]he homosexual...usually goes through years of conflict in our society. Why not remove the conflict by removing the social stigmata associated with homosexuality?" (VR Jan. 1971, 14-15). James L. Stoll wrote hopefully, "So our work is paying off! Future generations should be free to enjoy sharing love with any person. Repressive prejudice robs people of their selfworth and, by establishing that some people are better than others, gives 'the betters' power over others" (VR Oct. 1971, 9).

For many gay men, the domination of the heterosexual order led inevitably to self-hatred, to alienation from the self. "I felt I was queer, that I'd always be a queer, that everything - when I got to the bottom of things - was hopeless" (GS Aug.-Sept. 1970, 14). Although this experience was surely real and expressed often in the gay press of the period, it also became another point of moralizing among gay men, where gay libbers distinguished themselves from other gay men and from older cultural forms of gayness by claiming that such cultural practices were based in self-hatred. Discussions of self-hatred moved quickly from actual lived experience to a cultural-political sign detached from experience, where an individual gay man's behavior or politics were seen as signs of an unconscious (or conscious) self-hatred. It became emblematic of men who weren't strong enough or "out" enough or moral enough to shake off the effects of domination; self-hatred thus became a way for gay men to create in/out boundaries amongst themselves and to establish moral hierarchies in their social relations. For example, Gay Sunshine ran numerous articles that ar- 
gued that only a self-hating gay man would go to bars; only a selfhating gay man would have multiple partners; only a self-hating gay man would enjoy drag. Old-school "fairies" had, for some gay libbers, internalized the heterosexual's hatred of homosexuals by presenting a more feminine gender. ${ }^{24}$ " They [older gay men] are unable to imagine that gay is good. ...gay traditionalists are drawn towards astrology, the occult, and superstitious ideas of every sort. They desperately want to be heterosexual, but they believe the hand of cruel fate is set against them" (GS Jan. 1972, 3).

Other gay men saw a further form of alienation in the way they experienced their very bodies, their own embodied sexual selves. The Effeminist ran a series of articles in 1971 explaining how an anti-homosexual culture cuts gay men off from their bodies. First, The Effeminist made a feminist-inspired argument about the control of men's bodies in general.

The bodies of men of the wrong age (young) the wrong marital status (single) or the wrong class have always been so much meat to be used in ways useful to the dominant (straight, family) males. For this reason, we gay (powerless) males must of necessity of our condition be anti-war, and anti-imperialist. We are already a conquered territory. 1.2, 5-6.

But more to the point, the writers argued that heterosexual culture "mystifies" the gay body, keeping the gay man powerless, frozen, and small by keeping him from feeling his own body. "It is important you see that we be taught not to listen to our bodies, not to listen when our bodies know better than we do ... when we are being raped and fucked over" $(T E 1.2,5,12)$. They advised gay men to "pay attention to your body"; if they did so, they would know what was best for themselves and their lives and could wade through the false consciousness of heterosexism. "The system exploits the individual's intense longing for a bodily sensation of transcending the experience of alienation by promoting institutions which reinforce the tendency of alienated persons to misread body messages in their searches after pleasure. ... It goes for sex, too- that is the alienated contact that passes for sex in the socalled homosexual world." 
For other gay men, the most detrimental effect of domination was that it disrupted and often foreclosed the possibility of having genuine, deep relationships with each other. Early in 1963, The News had run a piece about the African American author James Baldwin, which focused on his disillusionment with the "gay underworld." Baldwin had been highly critical of gay men's lifestyles in the early 1960s and The News zeroed in on this particular aspect of Baldwin's critique. In the gay underworld, "'it is impossible to have either a lover or a friend, where the possibility of genuine human involvement has altogether ceased.' I would recommend the rest of the quotation as good advice" (TN Oct. 28, 1963). This feeling that real human relationships were impossible for gay men continued through the 1960 s, but the critique shifted its focus with the gay libbers in the early 1970s away from gay culture itself toward a critique of the society that produced the alienation.

Our relationships on the job, in school, at church could never be whole because it was not safe to express our sexual interests there. Therefore, at the end of the day or at the end of the week we went to where we knew gay people congregated: certain bars, baths, and parks. ... Society permitted only these meeting places because they were the means by which we were kept in our place. By restricting our meeting, society forced us to act our roles in our search for each other that supported heterosexual stereotypes of us. For example they wanted to believe that we are more impersonal in our sexual relationships.... First they made it dangerous for us to be open about sex in our regular relationships. Then they provided meeting places, which, because we were so easily exposed, were also dangerous. Anonymity became necessary for survival. ... Impersonal sex became an imposed way of life. ... Our oppression reached into our bedrooms. GS April 1972, 10.

For gay libbers, anonymous gay sex was not just a proclivity or a desire, but the result of oppression, where the straight society controlled gay sex by putting strict boundaries on where it could take place. For Gay Sunshine, this had the horrifying effect of deepening the alienation of gay men from their bodies and of reproduc- 
ing "stereotypes," which they hoped would decrease as gay men were liberated. Emmaus House also saw a connection between oppression and the inability to have meaningful relationships. For Douglas L. Brown, the effect of internalizing the guilt and hatred of straight society was to give up on gay community building and to revert to focusing on the next trick. ${ }^{25}$

\section{Confronting the Power of the Heterosexual Order}

From their experience of domination, gay men had to figure out how to overcome its effects and perhaps overthrow the regime that dominated them. They had to find a way out from under the expertise that authorized the dominating symbolic system of American culture. One writer expressed a common frustration with the expert and official discourses about homosexuality. "One is willing to excuse stupidity and fear in the uneducated, but the tolerance level is suppressed rapidly when the person spreading bilge is a 'learned' one" ( $V R$ Aug. 1968, 7). In earlier periods of American history, most men with same-sex desires had to either succumb to the pressures of the dominant discourse and live as heterosexuals, or they had to create alternative meanings on their own in private and often in isolation. Sometimes these men were lucky enough to find one of the various urban homosexual communities that gave a sub-cultural and communal context to their alternative meanings. ${ }^{26}$ What was changing in San Francisco between 1961 and 1972 was the scope of those sub-cultural contexts, which were in the process of being reconstituted as a counter-public, ${ }^{27}$ which actively and publicly engaged and fought against the dominant heterosexual order.

Gay men began by rejecting the psychiatric definitions of sexual pathology and engaged in outright attacks on the psychiatric establishment. "It is time that homosexuals rejected a philosophy that considers them 'sick' by definition" (VR June 1967, 23). ${ }^{28}$ The most obvious critique they leveled was that doctors' "studies" used psychiatric hospital patients as their samples. ${ }^{29}$ More confrontationally, both their experiences as gay men and their experiences with psychiatrists and psychiatric discourse in general 
led many gay men to an outright repudiation of psychiatric expertise. ${ }^{30}$ For them, psychiatry had been completely discredited precisely because the psychopathology of homosexuality made no sense in their experience. "Homosexuals are sick-sick of hearing uninformed, self-appointed authorities airing their personal prejudices and distortions as facts" (VR March 1967, 8). Frank Kameny of the Washington Mattachine wrote in San Francisco's press, "It is psychiatry and psychoanalysts which are sick and psychiatrists and psychoanalysis who are suffering from a faulty scientific identity and so are pathological" (VR Nov. 1970, 14-15). Don Jackson advised one young man not to see a psychiatrist because "psychiatrists are moralists and are unable to give good advice to homosexuals" (VR April 1971, 20-21).

Responding to a National Institute of Mental Health report in 1970, Agape in Action, a radical gay Christian publication, argued that mental health experts refuse to speak of heterosexuals in the same terms that they use for homosexuals, assuming that heterosexuals are uniformly well-adjusted. "The real meaning of this report is very simple: the government and the professions are engaged in a deliberate program of genocide - the destruction of a people" (AA Oct. 28, 1970, 7-8). This was not an extreme or isolated view. Gay Sunshine reported that efforts to "cure" homosexuals amounted to nothing less than the mass murder of gay people as a people. As the public debates about homosexuality increased in the early 1970s, so did the proponents of cure. "Gay Liberationists take all this as evidence of a monstrous conspiracy for the genocide of homosexuals" (GS June-July 1971, 11-12). Gay Sunshine called this trend a neo-Eugenics movement (GS June-July 1971, 11-12). ${ }^{31}$

In response to this threat, gay men and women began a tradition of zapping American Psychiatric Association meetings, beginning in San Francisco in 1970. In Washington, D.C., in 1971, gay activists actually got on the program and disrupted meetings about sexual deviance. ${ }^{32}$ And Dallas in 1972 activists excoriated participants for holding homosexuals to a different standard than heterosexuals. ${ }^{33}$ For these gay men, psychiatry was based on "a misinterpretation of cultural artifacts of the particularly distorted, 
warped, perverted sexual attitudes of the Victorian era in which Freud grew up" (VR June 1972). "That a noted psychiatrist should refer to two people of the same sex who enjoy each other as 'an affliction' illustrated his unscientific and moralistic judgment" ( $V R$ March 1971, 38-39). Thus, some gay men concluded that the very purpose of psychiatry was "To support and buttress the prejudices of society and to assist the bigots in the perpetration and perpetuation of their bigotry; and at least equally important (2) To destroy the homosexual's self-confidence and self-esteem, impair his or her self-image, degrade his or her basic human dignity" (VR June 1972). Thinking historically, one earlier Vector article foreshadowed Foucault as it traced the cultural history of the transition from controlling sex through "sin" to controlling sex through "sickness." "So a new vision of hell was created: That of Freud" (VR Jan. 1969, 16-17). ${ }^{34}$

Running a close second to psychiatry, religious definitions of homosexuality haunted many gay men their whole lives as they tried to leave behind the religious cultures of their youth. One man wrote that having been raised Southern Baptist, "as I hit adolescence, I had strong doubts about the worth of my intellect, my physical appearance and strength, my sexual desires, my ability to relate to people - in short, about myself" (GS Aug.-Sept. 1970, 14). In San Francisco, the church sought actively to intervene in the public sphere to control the sex lives of citizens. ${ }^{35}$ For many men, their religious separations were painful and life-shaping. "My homosexuality is what separated me from religion," wrote one man (VR Nov. 1970, 39, 43-44). Gay publications carried frequent engagements with religious definitions of sexuality and the power that religion exerted in enforcing the heterosexual order. "Clerics pitied the homosexual whose 'unnatural' behavior condemned him to one of the Dante fiery tortures" (VR Jan. 1969, 16-17). And Rabbi Schoel Myers, with extensive quoting from both the Torah and the Talmud, explained in no uncertain terms that "The attitude of the Jewish religion is, then, clear and unambiguous: homosexual relations are sinful" (VR May 1971, 24). In a backhanded effort to be charitable, the American Presbyterian general assembly in 1971 both affirmed that homosexuality is a sin, but urged 
the government to legalize it, because making it illegal simply persecuted the sick and afflicted. ${ }^{36}$ As with psychiatry, gay religious activists argued that notions of sin were meanings of sexuality imposed from the outside. The radical gay Christian publication Agape in Action argued that "the locus of sin with respect to the homosexual is in the imposition of the concept homosexuality, and not in the self-identity or expression of homosexual" ( $A A$ Aug. $25,1970,1)$. They argued that justice for homosexuals was an obligation of Jewish and Christian ethics. The Church's "silence will not do. Unspoken concern will not do. Rap sessions and lectures alone will not do. Justice is being demanded, and to render justice, for Christians and Jews, is not less than a requirement of our faith. One cannot choose not to render justice or to break the yoke of oppression. One must" (AA June 23, 1970).

In combination with the formation of gay religious organizations such as the Metropolitan Community Church, gay men reacted to the dominating religious meanings of homosexuality primarily by asserting themselves as simultaneously gay and religious. Bois Burke, an elderly chap and gay libber, argued that religion only seemed to be a problem "among the Catholics mainly, or those who are 'out' recently, or among the Mormons who are told they can't get into heaven unless they're married." Burke suggested that if religion was so important to them, they would have to "be able to take a double life of not confessing in church re: his sex life, but take in what he gets from the sermons" ( $V R$ June 1967, 18). ${ }^{37}$ In an informal survey, Vector readers responded overwhelmingly that gay men could be homosexual and Christian and that the ethical stances of Christianity did not conflict with homosexuality. ${ }^{38}$ Indeed, some gay men even actively chastised their gay brethren, warning them to "reconsider their atheistic posture" (letter from anonymous, $V R$ Sept. 1967, 16-17). Other gay men, such as Jack Miller, refused religiosity altogether, "so long as bigotry, narrow-mindedness, and prejudice with regard to race creed and sexual proclivities is so demonstratedly [sic] rife among church goers" (VR June 1967, 18).

Because of the history of intense persecution and equating of homosexuality with, many gay men insisted that to be truly liber- 
ated, one must leave the churches and synagogues behind altogether. Understandably, gay publications were filled with much anti-religious sentiment. Guy Strait argued that religious people err in pointing at the sins of the homosexual. "To make a spectacle of the variant to the exclusion of other forms of sexual expression is hardly becoming to those professing their beliefs" (TNAug. 19, 1963, 3-4). Strait and others who followed him, pointed out the hypocrisy of the religious judgment of the homosexual. "The church has been responsible for and has aggravated more wars and hatreds among men than any other source" (VR June 1967, 5). Activist gay men feared the collapse of the separation of church and state. One particularly angry man, Robert Koch, stated that religion "is the most retardant, destructive, regressive power in our culture. ...The most abominable edicts ... are the sexual ones delineating who with and how to have sex, and even so far as why to have sex. ... I think this [religion] is the sickest thing in our society. Who's worried about drag?" (VR June 1967, 18). Gay men saw that sex negativity in general came from Christianity and that "homoerotophobia" (later shortened to "homophobia") was born of Christian parentage ${ }^{39}$ Critiques against a gay religiosity rang loud during the early 1970s. Said one sarcastic writer, "Repentant at last, homosexual sinners found a new acceptance by heterosexuals everywhere" (VR Oct. 1971, 35). And further, "In America today, the gay churches stand spiritually vacated. Homosexuals are on their knees - a frightened and infernally dull lot-instead of on their feet. ... We don't want what heterosexuals have; heterosexuals should not want what we have" (VR Oct. 1971, 35). For many activists, gay religion was seen as taking gay men away from what really mattered: fighting domination and gaining liberation. For those critical of gay religiosity, religiosity could only be a sycophantic pandering to the heterosexual culture.

But those who considered themselves religious were numerous, and they were equally loud in demanding their right to create religious identities compatible with their homosexual identities.

What right has one gay brother or sister to tell another to get out of their churches, to give up their religious beliefs; attack- 
ing them in a most hateful and destructive way? There is something very wrong in all this. If some gays feel that their religious practices, faith and fellowship, bring more meaning into their lives, so be it. With all this talk by gays about 'liberation,' 'dignity' and 'the right to live as we desire,' perhaps all of us should rethink what these words mean when dealing with our gay brothers' or sisters' religious convictions and activities. $V R$ May 1972, 41.

Indeed in many ways, religious discourses seemed to be more tractable than psychiatry, as gay men and women simply formed new religious communities based on new interpretations of the religions of their childhoods.

San Francisco gay publications across the political spectrum published thought pieces rethinking Christian and Jewish theology to include positive views of homosexuality. One piece in $\mathrm{Vec}$ tor imagined Jesus as a human being with sex drives and included images of male nudes. The article gave scriptural evidence that perhaps Jesus was himself homosexual. ${ }^{40}$ Laud Humphreys, a sociologist and a minister, wrote a similar essay in 1970, arguing that Jesus as a human had to be sexual. "Had I proceeded with the logical extension of this central, Christian doctrine to proclaim that Jesus 'jacked off' as a teenager, my active ministry would never have lasted ten years" (VR Dec. 1970, 13-14, 38). He went on to claim that St. Paul was a "closeted queen" and that although the Bible doesn't say that Jesus had orgasms with the Apostles whom he loved, it does demonstrate special attention for his favorites, and notes that this was after all the Hellenistic world where teachers would have been expected to have sex with their students. This essay was also illustrated: a photo of naked young man, hairless, water in the background, arms outstretched in a cruciform. Dr. Paul Roberts agreed that Paul was probably gay and gives a radical rereading of Romans 1, wherein he says that Paul only condemns "unnatural" same-sex sex; so if it is natural to you, it cannot be a sin (see VR May 1971, 24). Thus, trying to change one's natural homosexuality to heterosexuality, for Dr. Roberts, was the real $\sin$. 
In addition to psychiatry and religion, gay men had to contend with the mass media, which played a pervasive role in reproducing the dominating heterosexual order. One activist man writing for Vector in 1970 argued that gay men had to begin using the tools of the mass media to overcome the negative images and assumptions of the dominant culture. "[T] he mass media could break down the stereotyped images, whereas now they only reinforce these images" (VR Nov. 1970, 39, 43-44). Mass media through the 1960s and early 1970s did more than reinforce negative images of homosexuals - it was the primary means of the reproduction of the culture necessary to justify the systematic domination of gay men as individuals and communities. The mainstream San Francisco newspapers, both the Chronicle and the Examiner actively commented on the "homosexual problem" in the city ${ }^{41}$; but no less important was the coverage of the national media, radio, ${ }^{42}$ television, film, and books. Gay men had an uneasy relationship to these representations as, on the one hand, they were at least some kind of representation. On the other hand, such representations were overwhelmingly inaccurate and sensationalized, and especially problematic, give that they were completely uncritical about why gay men may live or behave in certain ways. By mid-1967, gay men were beginning to feel overwhelmed by the coverage given homosexuality in the popular media. "In the past few years we have been subjected to a barrage of information on homosexuality from the press, television, radio and the national magazines" ( $V R$ May 1967, 10). We find in gay publications' responses to mass media representations echoes of their struggles to make meaning of their homosexuality out of their experiences.

\section{Fighting Back: Refusing Domination and Its Effects}

By the early 1970s, many activists had grown impatient and angry; they had come to see domination as a direct result of gay men's refusal to fight for their own lives.

In our society, nobody cares what happens to a fag. We believe the homosexual is also to blame for the depressing life he often 
leads. He has allowed it to happen. He has allowed society to force him into a subordinate position. He has not fought back. Many homosexuals have depended on and supported a society which rejects them. Too often the homosexual has played the role. IA 1.3.

There came to be an active and loud refusal of the dominant meanings of homosexuality and an awesome work to replace them with new meanings. But such active refusals go back well before the gay libbers. Indeed, the value of "respectability" of earlier activists can be read as a refusal of dominant definitions of homosexuality. For example, "[H]omosexuals often behave as irresponsibly as they have been branded by society and by themselves. This myth of irresponsibility has to be shattered" (VR Jan. 1966, 8). In other words, where the dominant image of the homosexual was a shiftless criminal, the insistence on good citizenship was a direct refusal of that image for those activists in the mid-1960s. From the early 1960s when they had begun to insist on their place in the public sphere, gay men felt they had to shatter what they called "stereotypes," to throw off the oppressive definitions imposed from the outside. So the gay libbers were simply continuing in an already-established vein; but they added an assertion of a gay self. "The best news is that many young people are coming out vocally as homosexuals and expressing themselves. There is a great deal of 'Well, fuck you, if you don't accept me" (VR March. 1972, 4).

In this cultural battle to throw off domination by claiming the right to define themselves, gay men began to focus on the connection of the heterosexual order with their relationships to heterosexuals. "The term 'fag' when used by a heterosexual (or even a homosexual for that matter) is not innocent, no matter how offhanded it seems; it reflects the same old condescending attitude, the same disgusting overtones of 'queer' and 'pervert' and degenerate' by which 'right thinking' heterosexuals attempt to maintain their supposed superiority to homosexuals" (VR July 1970, 1011). In the face of this superiority, Gay Sunshine urged gay men to refuse the acceptance of heterosexuals. "And the straight man would have us believe that this [heterosexual marriage] is natural 
and normal and then expect us to applaud and praise him when he condescends to accept us. ... who is he with his perverted asexual notions and behavioral patterns to accept us?" (GS Oct.-Nov. 1971, $7)$. One of the most enduring ways that gay men refused the heterosexual culture in their publications was to produce campy spoofs of heterosexual fears of gay men. ${ }^{43}$ "The straight people of San Francisco are hurriedly looking for a community in which they can live and form some identity. ... The President caused an uproar in the nation today by lifting the ban on heterosexuality" ( $A G$ April 15, 1971, 1). But why ask for acceptance when you have your own culture? "We also find that even though this society has tried to crush our ideas of culture and society they have survived and now are surging toward a greater uniqueness and awareness" (GS Nov. 1970, 8-9).

This grew quickly into anger and violent emotion, as evidenced in Charles Thorp's poem about raping a straight guy ${ }^{44}$ or Keith St. Clare's poem about the violent side of gay male sex. ${ }^{45}$ Especially the tone of San Francisco Gay Free Press and The Effeminist grew more and more confrontational and threatening. "I want to tell you that I'm proud of me, what I am, my culture, my openness, my gayness and what I do, feel and say, so damn it, leave me alone, stop interfering or else" (SFGFP Dec. 1970, 5). This article from the SFGFP attacked straight men and rejected any form of masculine identity coming from heterosexual males.

And what does sisterhood [among gay men] actually mean to you [straight men]? You don't even know because you've never experienced brotherhood. You still want to exploit and use women as sexual objects for your pleasures and bondage just to keep on provin' you're a masculinity [sic], to cover over your errors and frailties. ... I can tell you right now straight man, I'm not going to feed your feeble-minded ego any longer and neither will my sisters.

The writer goes on to reject heterosexual men's sexual privilege.

At this time, as a brother to me your worth is nil... I am not like you nor want to do as you do, ever. I don't want to suck 
your cock, or fuck you, so you needn't worry. I wouldn't touch you with a ten-foot erection. You aren't worthy of my love because you can't accept me as your brother and love me. I'm rising up gay to smash your cock-power, understand?

And the writer rejects the backhanded help of the straight man. "I don't need your straight ideals and political philosophies to guide me or support me. ... My liberation will be accomplished my way on my terms liken [sic] to that which my brothers and sisters agree will best free us, totally and complete."

For its part, Agape in Action took a similar tone of defiance in its anger.

It's hard to hold onto what you [straight males] do to us [gay males]. I've even got a cock, too, just like you. Just so, I'm still just the hole in your head. I don't exist except in your head, you, the all-absorbing cosmic one. I'm just a queer. I'm just like a woman. ... You stick all sorts of instruments up me, thermometers, fingers, fingers with rubber protective coverings, sterilized metal probes, some with lights to see the cavities, the ruptures. You poke and cram. You shoot, you kill. And still you can't find me. You've got radar, you've got lasers, in hopes I'm nowhere. I' $m$ just the hole in your head. I'm the other, the other person you're not, the outside world. You call me woman. You call me queer. You call me slave. You're too busy to know me. You define me. You steal my life to fill the hole in your head. You tell me who I am. You never let me be. Poke, push, and scram. Student, workers, woman, queer. AA Feb. 1971.

Elijah, writing for The Effeminist, expressed his anger and frustration in violent images.

My brother says I am a pig — [like] a straight man — because I wanted a gun to kill straights last week. ... No brother, they do have power. I am unable to fight them one body alone without help (none of you faggots are showing solidarity, that's for sure). I demand to be free of their daily assault on my body, my mind, on my soul. They will back off or die.... But the demand is met at once by force. ... You who sit and do not help when I am under attack — what do you know of queerness? .... Did you 
ever feel the assault of gestures, his loud voice, his eyes with their gestures of dominance, his controlling handshakes, his assumption of his right to fully occupy any assumption of his right to rule, to be heard, to be desired, to have all he wants and to destroy all else? ... You [my gay brother] dare to say I am straight when I defend my life? You pig. TE 1.2, 6.

For many men, these intense feelings of anger, frustration, and violence underlay their continual (re)assertion of their gay selves, an ongoing project of claiming their freedom of personhood by insisting on their existence as gay individuals, whole and good human beings. In the cultural environment of 1960s America, gay men had to continually remind themselves that they were even human. "The Navy says I am undesirable. The sexologists say I'm sick. The government says I'm a poor security risk. The law says I'm a criminal. The Church says I'm a sinner. The man in the street thinks I'm queer' (CN June 22, 1964, 6). What so frustrated gay men was that it seemed with each step toward building a life for themselves, the dominant culture responded with new forms of oppression.

We Gay males discover our histories, our lives. The Man suppressed our existence and isolated us from one another. We discovered we were human and they called it homosexuality. We discovered what it means to be a man in America and they called it self-hate. We discovered ourselves, and they said we were afraid of women. We discovered their secret, their empty and vicious lives, and they called us outlaws. TE 1.2, 11.

So gay men had to take up the task of a continual re-assertion of the self along with their refusal of the straight norm. "'We must give up the 'Amos and Andy' syndrome,' SIR President Tom Maurer, told this crowd. 'Let us stop playing society's game. Begin to say, "I'm me- and if you don't like it that's YOUR problem,"," (VR Oct. 1970, 13). Gay Sunshine echoed Maurer's sentiment. "Straights have ruled us too long. It's time to be YOURSELF! Don't blend-in with Straight people - oppressing yourself. BLATANT IS BEAUTIFUL!" (GS Oct. 1970, 9). The feeling had be- 
come, by the 1970 s, that gay men should no longer have to adjust to society, but that they were fine as they were. "The societal norm must adjust to us, must adjust to the fact that we exist, that we emerged out of and were conditioned by a straight/queer society, and that we have as rightful a place in society as the next person" (GS Oct.-Nov. 1971, 7). And at its core, this most often amounted to insisting, over and over again, on their basic humanity. "The next time someone tells a 'queer' joke, don't laugh, look at him and say, 'I'm gay.' ... We are humans, not something to be laughed at" (IA 1.2,3).

\section{From Domination to Meaning Production}

Gay men's responses to symbolic violence and domination were varied and hotly contested. In the 1960 s, gay men began to actively transform, co-opt, resist and reject the official definitions of homosexuality according to their experiences. In other words, as they acted to transform their environment through the establishment of a gay counter-public and a gay community, they also transformed their relationship to their knowledge of homosexuality, creating the cognitive space they would need to produce new knowledge of gay maleness. Their experiences, ever more divergent from the dominant, outsider definitions of homosexuality, demanded new and more complex meanings of homosexuality that would match their experiences of being gay, being public, and being part of a gay community. What eventually arose in the gay press of the 1960s was the struggle for the meaning of "gay" (or "homosexual") itself, a struggle which engaged official discourses, to be sure, but more importantly, a struggle in which gay men engaged each other to make their sexuality, their desires and behaviors, intelligible and meaningful such that "gay" could enable the consummations of their sexual, social, and relational desires, providing an environment that supported their personhood rather than forcing their withdrawal and alienation.

As the 1970s dawned, gay men of every political ilk insisted more and more loudly that only they could speak for themselves, that only they were qualified to give definitions, only they were 
qualified to assign meaning, and only they were capable of understanding what it meant to be gay-for it was their feelings and desires, their interior lives, their experience of oppression, and their sexuality. By 1971, gay men were asserting a myriad of different explanations for their sexuality and actively arguing with each other about what it meant to be a homosexual. A handful of general categories emerged as coherent and meaningful for them: a democratic choice (lifestyle, taste, proclivity); genetic (inborn); natural (connected to the larger, natural historical world, and sometimes to a more spiritual understanding of "natural"); and acquired (learned, cultural). From within their experiences of oppression, gay men constantly had to reevaluate the meaning of their samesex desire for sex and relationships with other men. Their experiences of domination played together with how they positioned themselves vis-à-vis community building to form their basic stances on the nature of homosexuality. Thus, these general categories of meaning overlapped and individuals and groups often held contradictory meanings simultaneously, or adopted and shed meanings as they were situationally expedient.

In contexts where traditional citizenship and recognition were the predominant values, the idea that homosexuality was merely a sexual choice, a taste like any other, held sway. ${ }^{46}$ Guy Strait compared homosexuality to liking escargot when one's parents do not like eating snails. ${ }^{47}$ Strait argued for job non-discrimination on the basis that "Homosexuality, in the main, is a way of life, either by choice or by inclination, and it has no bearing whatsoever on ability" (CN May 25, 1964, 8-9); here, he changed culinary analogies: it is much more like eating turnips than escargot. Thus, homosexuality was seen as "among the valid choices people can choose is homosexual experience" (TT Sept. 1965, 1, 4). The experience of oppression by the state combined with the desire for integration and full citizenship in the public sphere made sexuality intelligible as a choice, one best determined by individuals without interference from an outside group or institution..$^{48}$ One writer even argued that as homosexuality became a valid choice in American culture, there would be a noted increase in homosexuality, because many men refused the homosexual choice simply because society forbade it. ${ }^{49}$ 
Gay men could easily address the problem of situational homosexuality, which Kinsey had treated at length, ${ }^{50}$ if homosexuality writ large were simply a question of taste and choice. "I have met considerable number of persons who were formerly homosexual ... [H]omosexuality is not a permanent state with every person who happens at any particular time to be homosexual,"(VR Jan. 1969, 16-17). The writer notes, however, that for those who move in and out of homosexuality, perhaps "their desires were relatively undirected all along." Later in the period, gay men continued to use the choice argument as an inroad to the public sphere, insisting that homosexuality was merely one lifestyle choice among many, and therefore should not fall under the purview of governmental control. ${ }^{51}$ Ironically, this overlapped with the arguments of the anti-gay psychiatric establishment, which was agitating for enforced cures. But for many gay men, the argument of choice failed to answer fundamental questions about their sexuality. "The current 'up front' attitude among some homosexuals is that homosexuality is their preference. This is a social attitude adopted to express the right of every man to freedom of choice, but it still doesn't explain the choice" (VR June 1972). In other words, while individuals may indeed choose their sexual partners, it doesn't explain why they make the choices they do.

References to the inherency of homosexuality, to its inbornness, first began to circulate in the gay press in the mid-1960s. Gay men mingled these explanations of inbornness with claims to the power of their sexuality in their lives and with their direct confrontation with the dominant psychopathological influences of psychiatry. Here, homosexuality was seen as instinctual and hereditary. Town Talk referred often to the "sex instinct," rather than to sexuality. ${ }^{52}$ For some, this turn to instinct pointed up a beauty or a kind of spiritual experience of sexuality. "True homosexuals today, enduring the ceaseless ignorant drivel of psychiatry and knowing that none of such exorcisms in any way even begin to touch the core of that singing glory they carry within themselves, must now at last recognize that overpowering call within — as just such an instinct" $(V G 2.1)$. Not surprisingly, many gay men rested their arguments for heredity on Havelock Ellis. ${ }^{53}$ "To begin with, it must 
be realized that a determining hereditary factor operates in the development of homosexuality. Havelock Ellis preferred to say that there is a 'predisposition,' and used the parallel between homosexuality and color-blindness" (VR March-April 1968, 20-21). This particular author goes on to say that in this vein, homosexual is a hereditary capacity, a theme that will emerge throughout the latter part of the decade as many gay men saw themselves as being gifted to be able to love other men.

In 1971, Vector ran a story about the causes of homosexuality and quoted Evelyn Hooker's famous article in which she argues that gay men turn to genetics as a means to justify their homosexuality to the larger society (see $V R$ April 1971, 5).${ }^{54}$ Although its prominence among gay men declined during the 1960 s, the feeling that their gayness was inborn remained a strong theme. Tom Mauer wrote in response to a young man that had written to Ann Landers, "Whatever you do, Woody, let your sexual orientation come out of you! It's there; you can't change it nor can any therapist. What you can do is discover what it is. But if you choose a sexual life style that violates your sexual orientation, you'll make a tragedy of your life and undoubtedly one or two other lives as well" (VR April 1971, 20-21). Thus, homosexuality was experienced and defined as a kind of truth of the self. Many men expressed the feeling that "for as long as I can remember, I knew I was somehow different" (VR Aug. 1971, 36-37). Boris Korinsky, writing about his discharge from the military, quipped, "I can't remember ever not being a homosexual." (VR Sept. 1971, 10-11). And "Jackie" described his childhood in Texas where his parents accepted early on that he was different. "Perhaps my childhood wasn't an exciting one, certainly there were no great emotional problems, but form the moment my body first became aware of sex, I have been solely oriented towards men. I don't blame this on anyone, for to me there is no blame, because homosexuality is natural to me. And I am glad" (VR Nov. 1967, 12-13). Note the homosexuality was seen here as a source of happiness, but that it was the particular environment of his childhood that allowed this man to evolve a highly unusual view of his sexuality for the time period. The biological view of homosexuality led to explanations 
of gay men's anxiety ${ }^{55}$ and in one case proposals for how society can deal with the "genetic carriers of homosexuality." 56

Gay men continued their refusal of dominant explanations of homosexuality in their turn to "Nature," a kind of catch-all category for gay men's struggle to make their sexualities intelligible to themselves and to situate themselves with self-respect vis-à-vis the dominant culture. ${ }^{57}$ Lou Harrison argued that gay men will always exist because their existence is natural; nature reproduces gay men even though they can't reproduce themselves. "Our ranks are continually and regularly replenished from nature" (VR Oct. 1967, 18-19). Another man noted simply that homosexuality was common throughout the animal kingdom, making the very idea of "abnormality" absurd (see VR Feb.-March 1967, 11).$^{58}$ Many gay men took the naturalness of their sexuality a step further, finding in nature the meaning of homosexuality.

You, Homosexual, are you perverse? Is it unnatural for you to view the brawny lad with a delightful eye? Are you going against YOUR NATURE when you express yourself sexually? ... My hunger for food, my thirst for water, my desire for homo sex is MY NATURE. Laws do not quiet my appetite. Prison will not quench my thirst, reintegration will not appease my sexual nature. I be that which I be. Please burn all the witches, dismember all the heretics, destroy all non-Aryans, build barbed wire fences around all the cities, then, my country confiscate my innards. But only then. VR Oct. 1967, 23.

Importantly, the naturalness of their sexuality conflicted with their experiences of growing up in a straight world. "We knew, without being knowledgeable, that it was not 'ordinary' to feel such deep desire and passion for 'one of our own kind.' ... those with a deep rooted homosexual predilection eventually recognize that the practices in the barn-bush-basement [with friends] meant more to them than they did to their playmates" (VR Oct. 1968, 6). Despite these intense pressures, "we found it impossible to deny the profound emotion of love for our own kind." So for many gay men, "The American fantasy of growing up straight with no question of an alternative way of life is not realistically concerned with 
the way persons are naturally born or made" (VR Nov. 1968, 5). Thus, "We declare that love between those of the same sex, however incomprehensible, absurd, or even abhorrent it is to the feelings of 'normal' people, is neither a vice nor a disease, it is not a mockery of nature, but a manifestation of nature; it is an erotic variation that has been observed among all peoples on earth since the dawn of human thought" ( $V G 1.7,2,5$, original in all caps).

Ultimately, the argument came down to what exactly "natural" might mean, and what part of homosexuality was natural. And what many argued in the 1970s was that it was the capacity to love someone of the same sex - the aptitude for same-sex love - that was natural. ${ }^{59}$ And for those who valued authenticity, this nature was deeply personal and deeply connected to the self. "And what is natural, the straight/queer world had better begin to realize is not some immutable, cosmic law laid down by God or some such. What is natural is what springs from the inner source of each person's being" (GS Oct.-Nov. 1971, 7). Still others rejected both the genetic and the natural arguments, which they saw as a "degrading, demeaning, dehumanizing ...' anatomy is destiny' theory. Our genital organs are our appendages; we are not appendages of our genital organs" (VR June 1972).

And so the conversation returned to the idea of choice, but with the added weight of cultural conditioning behind it. "[P]sychological social and cultural factors outweigh constitutional and glandular factors in producing sexual orientations" (VR March 1969, 16-17). For at least one writer, the experience of social oppression made homosexuality primary. "'Our homosexuality is a crucial part of our identity, not because of anything intrinsic, but because social oppression has made it so" (VR Jan. 1972, 32). Critics of the genetic model argued that biological explanations failed to elicit the depth of their experience. "But this [genetic explanation of homosexuality] is at best superficial because the reality of being goes to the core of a personality and this has ultimately nothing to do with genetics" ( $V R$ Jan. 1969, 7, 22). As early as 1965, Town Talk anchored sexuality in social mores. "Heterosexuality is not a scientific norm, but a value norm, and value norms are subject to change" (TT Sept. 1965, 1,4). Many of these 
arguments of values were rooted in Freudian conceptions of the self. "Conscience (superego) is developed within a very small unit of society. ... These cultural determinants are formed within the microcosm of the family unit" (VR Jan. 1969, 7, 22). Some went so far as to argue that "a plausible assumption was that with no cultural pressure in either direction, fifty percent of children would grow up to be mainly heterosexual and fifty percent homosexual. Or there is the possibility that adult sexual preferences might conform to the normal curve distribution" (VR March 1969, 16-17). ${ }^{60}$ This kind of sexual blank slate was most fully embraced by gay libbers who felt that human beings were naturally bisexual, that Freud's polymorphous perversity meant a natural state without sexual categories based on sexual object choice at all. Carl Whitman would eventually echo Freud, arguing that "Nature leaves undefined the object of sexual desire. The gender of that object has been imposed socially" (SFFP Dec. 22-Jan. 7, 1970, 3-5). For some, this meant that sexual object choice was indeed mutable, whereas for others, the social explanation did not necessarily mean that homosexuality was mutable. "The individual whose identity is psycho-dynamically involved in homosexuality will remain so oriented" (VR Sept. 1971, 30-31).

It is not my purpose to answer the ponderous etiological question here, but rather to highlight the problems gay men had as they sought to explain their homosexuality from a subordinate sociocultural position. Symbolic domination of the heterosexual order forced gay men to ask themselves questions about their desire and about their relationships and about their sex acts that no one else had to ask: Is my desire natural? Is my desire a choice? Once they had begun the process of shirking the heterosexual order, they were left with a cognitive void that required a meaning of homosexuality. Their varied positions vis-à-vis the dominant culture produced varied and contradictory meanings of "gay" that served different purposes in different contexts. Gay men were seeking to produce explanations or categories that would make intelligible both their sexuality and their experience of their sexuality in relationship to the dominant culture and their experience of trying to make sense 
of it all with each other in community. The questions they asked each other were many and varied: If homosexuality is a choice, why is heterosexuality not a real choice for homosexuals? If it's genetic or instinctual, then why not seek to cure it as one does other genetic diseases? If it's natural, why are homosexuals so different from each other-why is behavior and desire so diverse among homosexuals? If it's socially determined, where does the desire come from and why isn't it simple to switch one's desired object? The conflict over the nature and meaning of homosexuality went round and round (and continues to do so) among gay men as no explanation seemed to fully give voice to their experience of homosexuality and all of them left the individual and community open to further oppression. "[A]11 homosexuals have been forced to question the validity of the rationalizations that have made the homosexual community pliable and weak in the past" (CHFN May 13, 1969). Thus, inasmuch as the heterosexual order continued to structure the consummation of desires, both relational and sexual, gay men could not settle (and have not settled) on any stable explanation or definition of their homosexuality, for neither the complex environment nor their own desires could allow it, inasmuch as all of the meanings they produced made sense within their contradictory experiences of domination.

\section{Notes}

${ }^{1}$ See for example Robert J. Corber, Homosexuality in Cold War America: Resistance and the Crisis of Masculinity (Duke University Press: Durham, 1997); John D’Emilio, Sexual Politics, Sexual Communities: The Making of a Homosexual Minority in the United States, 19401970 (Chicago University Press: Chicago, 1983); and David K. Johnson, The Lavender Scare: The Cold War Persecution of Gays and Lesbians in the Federal Government (Chicago University Press: Chicago, 2004).

${ }^{2}$ The San Francisco gay publications cited in and consulted for this paper include (abbreviations in parentheses): The LCE News (LN), 19621963; The News (TN), 1963; Citizens News (CN), 1964-1966; Town Talk (TT), 1964-1966; Vector (VR), 1964-1972; Vanguard (VG), 1966-1967, 1969; CHF Newsletter (CHFN), 1969; San Francisco Free Press (SFFP), 1969-1970; San Francisco Gay Free Press (SFGFP), 1970; Agape and 
Action (AA), 1970-1971; Gay Sunshine (GS) 1970-1972; The Effeminist (TE), 1971; Adz Gayzette (AG), 1970-1971; I Am: Oracle of the Gay Emmaus (IA), 1971; and The Bay Area Reporter (BAR), 1971-1972.

${ }^{3}$ For details of San Francisco's sexual openness, see Nan Boyd, Wide Open Town: A History of Queer San Francisco to 1965 (California University Press: Berkeley, 2003).

${ }^{4}$ Here, I am adapting concepts gleaned from Foucault's analysis of the 19th century prison. See Michèl Foucault, Discipline and Punish: The Birth of the Prison [1975], trans. Alan Sheridan [1977] (Vintage Books: New York, 1995).

${ }^{5}$ See The News Sept. 16, 1963, 1-2; CN May 25, 1964, 8-9; June 22, 1964, 6; Aug. 3, 1964, 6-8; 4.5, 1, 2; TT Oct.-Nov. 1965, 8; VR May 1967, 13;

${ }^{6}$ See $V R$ June 1965, 9.

${ }^{7}$ See letters from J.F.K. and from R.L.J., VR Dec. 1968, 16-18.

${ }^{8}$ See $C N 3.22$.

${ }^{9}$ See $C N$ Feb. 1964, 1; May 25, 1964, 8-9; April 1967, 20-21, 29; letter from R.P., $V R$ June 1967, 33;

${ }^{10}$ See letter from Hans Shultz, VR Sept. 1971, 36.

${ }^{11}$ See $C N$ May 25, 1964, 8-9.

${ }^{12}$ See TN Dec. 23, 1963, 1; CN May 4, 1964, 10;

${ }^{13}$ See Joan W. Scott, "The Evidence of Experience," in The Lesbian and Gay Studies Reader, eds., Henry Abelove, Michele Aina Barale, and David M. Halperin (Routledge: New York, 1993) 397-415.

${ }^{14}$ From "The Need for a Recovery of Philosophy," quoted in Robert. B. Westbrook, John Dewey and American Democracy (Cornell UP: Ithaca, 1993): 127.

${ }^{15}$ See Westbrook's explanation, Ibid., 323.

${ }^{16}$ Explained in Ibid., 345.

${ }^{17}$ See VR Dec. 1969, 10.

${ }^{18}$ I am adapting this concept from Pierre Bourdieu's Masculine Domination (Stanford University Press: Palo Alto, 2001). See especially pp. 9-23 and 34-38. I find the term "symbolic domination" prefereable to "discourse" and "oppression" both of which seem to have lost their analytical specificity in their common usage in the social and cultural sciences. I will use "symbolic domination" and "symbolic violence" to refer to the domination produced by systems of symbols which are in turn enacted and internalized by individuals who incorporate them into their perceptions, their attitudes, their dispositions, and their practices (or as Bourdieu would say, in their habitus). Herein I will refer specifically to the "heterosexual order" as the dominating symbolic system that legiti- 
mates the practices of a kind of heterosexuality and instills in individuals the values of that order to the effect of structuring the culture and social relations of those who live under its regime.

${ }^{19}$ See also VR Feb. 1972, 35.

${ }^{20}$ See Michael Warner, "Introduction" in Fear of a Queer Planet: Queer Politics and Social Theory (Minnesota University Press: Minneapolis, 1993), especially pp. xxi-xxv.

${ }^{21}$ See also VR Sept. 1969, 20-21, 30; SFGFP Nov. 1970, 4-5, 12;

${ }^{22}$ See also $V R$ Nov. 1970, 14-15; Jan. 1971, 14-15; and letter from Bob Hart, April 1971, 20-21.

${ }^{23}$ Fred, a man "cured" of his homosexual, argued that his behaviors had been "used by me in an attempt to cover up my corrupt crumbling life by wildly attacking society and everyone in it." $V R$ July 1970, 18-19, 41.

${ }^{24}$ See GS Jan. 1972, 3.

${ }^{25}$ See $I A$ 1.2., 3.

${ }^{26}$ For a detailed discussion of these dynamics at the turn of the 20th century in one urban center, see George Chauncy, Gay New York: Gender, Urban Culture, and the Making of the Gay Male World, 1890-1940 (Basic Books: New York, 1994); for a like description of San Francisco, see Boyd, Wide Open Town.

${ }^{27}$ In the sense explained by Nancy Fraser, as a public which forms contrary to the power and dominating effects of the official public sphere and its institutions. See "Rethinking the Public Sphere: A Contribution to the Critique of the Actually Existing Democracy" in Habermas and the Public Sphere, ed. by Craig Calhoun (MIT Press; Cambridge, Massachusetts, 1992): 137.

${ }^{28}$ See also $C N$ May 25, 1964, 8-9.

${ }^{29}$ See $V R$ Nov. 1970, 14-15; Feb. 1972, 35.

${ }^{30}$ From time to time, the gay press published positive notes from psychiatrists who had similar findings to Evelyn Hooker's studies in the late 1950s. See for example VR Oct. 1970, 48 and GS Jan. 1971, 5.

${ }^{31}$ Ironically, the writer slipped into a bit of anti-Semitism here as he blames homophobia on Jews, locating sexology as a Jewish intellectual tradition.

${ }^{32}$ That year, the APA voted to reclassify homosexuality as a "sexual perversion." Zappers disrupted a panel discussion on aversion therapy, participated in a panel with Dr. Bieber, an anti-gay hawker of gay cures, and held an independent panel on the last day they entitled, "Life Styles of Non-patient Homosexuals." See VR July 1971, 34-35; Aug. 1971, 3637; and GS June-July 1971, 11-12.

${ }^{33}$ See VR June 1972, 38. 
${ }^{34}$ Another expert, Edmund Bergler, and his book, One Thousand Homosexuals, resurfaced during the 1960s and was duly excoriated in Vector as so much Freudian mumbo-jumbo based on a non-scientific sample of mentally ill men who happened to be homosexual. See $V R$ Jan. 1969, 16-17.

${ }^{35}$ See for example $V R$ Nov. 1968, 5.

${ }^{36}$ For a full reprint of the statement which was not officially accepted by the General Assembly, see VR Aug. 1971, 50. There was also much coverage of the more liberal clergy who worked for an acceptance of the homosexual within various Christian churches. See for example $C N 4.5$, 1; VR July 1969, 17; "Gay Catholics: A First Step," AG April 22, 1971, 1; VG 1.7.29; VR Sept. 1970, 22-23; and June 1972, 9.

${ }^{37}$ Burke wrote a series of newsletters that he sent to friends, expounding his experiences as a gay man in San Francisco. A few of these survive and are held in the GLBTHS's archives in San Francisco.

${ }^{38}$ See $V R$ June 1967,18 . In a later survey, readers refused to disclose their religious affiliation. See VR April 1971, 5.

${ }^{39}$ See $V R$ Feb.-March 1968, 11.

${ }^{40}$ See $V R$ Dec. 1969, 20-21. See also a similar argument in GS Aug.Sept. 1971, 11.

${ }^{41}$ See for example: Kenneth Rexroth, "About the Homosexual," reprinted from The San Francisco Examiner 14 June, 1964, in CN 22 June, 1964, 8; and Guy Wright, "You Fellahs Should Be Discreet," reprinted from the San Francisco Call-Bulletin, in CN 4.4 (Nov. 1964), 5.

${ }^{42}$ One young gay man was interviewed on the radio, and experienced the way the media controls information first-hand. Guy Strait was critical of the man's behavior on the air: "The brash young men who did not understand the difference between publicity and notoriety arranged for radio time on KMPX-FM. The first program was cut off the air when the word 'gay' was mentioned." See $C N$ 3.22, 7.

${ }^{43}$ Guy Strait started this early on in his publication of a satire of LIFE Magazine's issue about homosexuality. See CN July 20, 1964. In the early 1970s, Vector ran several such spoofs. The first was a twoissue "exclusive," "I Am Straight: The Heart Rending Story of One Man's Failure as a Homosexual," in which they panned the coming out process. See VR July 1970, 27. In May 1971, the second one was entitled "Heterosexuality Exposed! The Private and Public Life of the Straight Ones." See VR May 1971, 10-11. And in February 1972, the Bay Area Reporter began a series by Don Jackson entitled "Everything You've Always Wanted to Know about Heterosexuality but Were Afraid to Ask." See BAR April 15, 1972. 
${ }^{44}$ See $S F F G P$ Nov. 1970, 11.

${ }^{45}$ See $V G$ March 1967.

${ }^{46}$ See $T N$ May 17, 1963, 1.

${ }^{47}$ See TN Aug. 19, 1963, 3-4.

${ }^{48}$ Thomas M. Edwards even argued that some men choose homosexuality in order to avoid their civic and social responsibilities. See Oct. 1967, 18-19.

${ }^{49}$ See $V R$ April 1968, 20-21.

${ }^{50}$ Most notably in the highly influential Sexual Behavior in the Human Male (W.B. Saunders: Philadelphia, 1948).

${ }^{51}$ See for example $V R$ Feb. 1972, 11.

${ }^{52}$ See for example TT Jan. 1965, 1-2, 4. Another man quoted Ralph Waldo Emerson to connect instinct to happiness in life: "If the single man plant himself indomitably on his instincts, and there abide, the huge world will come round to him." See TN Aug. 19, 1963, 3-4.

${ }^{53}$ A turn of the century sexologist who argued that sexual "inversion" was congenital and therefore should be decriminalized. See especially Studies in the Psychology of Sex (Random House: New York, 1936).

${ }^{54}$ In the late 1950s, Hooker found that the majority of the Los Angeles gay men she interviewed believed they were "born that way"; more importantly, her study revealed that gay men had the same emotional stability as their straight counterparts, revealing no difference whatsoever in their rates of emotional disturbance or mental illness. Her published works on the topic are numerous.

55 "Men who are genetically homosexual but who have been socially conditioned to view homosexuality negatively will have a high degree of anxiety," VR Jan. 1972, 14.

${ }^{56}$ See review of Norman C. Murphy, Anxiety, Homosexual Attitude, Duration of Time since Initial Explicitly Sexual Response, and Number of Explicitly Sexual Responses in VR Jan. 1972, 14. An earlier Vector had warned readers against genetic explanations of homosexuality: "What must be of great concern is that the secrets of the bio-chemical nature of conditioning of man is on the verge of being discovered. In the hands of our present misguided societal leadership, me could find such potent knowledge misused, wherein the very worth of natural man is destroyed." See VR Jan. 1969, 16-17.

${ }^{57}$ For some, the argument for naturalness made obvious sense in countering the anti-sodomy laws throughout the United States. See for example, $V R$ June 1972, 34-35.

${ }^{58}$ A recent book has traced wildlife biologists' reticence to study the same-sex behavior of animals. See Bruce Bagemihl, Biological Exuber- 
ance: Animal Homosexuality and Natural Diversity (St. Martin's: New York, 1999).

${ }^{59}$ See letter from Martha Shelley, GS Aug.-Sept. 1970, 12.

${ }^{60}$ See also $V R$ Nov. 1965, 6. 